This is an Open Access article, distributed under the terms of the Creative Commons AttributionNonCommercial-ShareAlike licence (http://creativecommons.org/licenses/by-nc-sa/4.0/), which permits noncommercial re-use, distribution, and reproduction in any medium, provided the same Creative Commons licence is included and the original work is properly cited. The written permission of Cambridge University Press must be obtained for commercial re-use.

\title{
All these Fantastic Cultures? Research History and Regionalization in the Late Palaeolithic Tanged Point Cultures of Eastern Europe
}

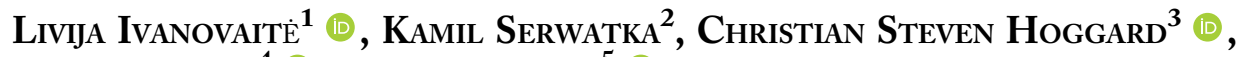 \\ Florian SAuer ${ }^{4}$ (i) AND Felix RIEDE ${ }^{5}$ [1) \\ ${ }^{1}$ Museum of Copenhagen, Denmark \\ ${ }^{2}$ Archaeological and Ethnographic Museum of Eódź, Poland \\ ${ }^{3}$ University of Southampton, United Kingdom \\ ${ }^{4}$ University of Cologne, Köln, Germany \\ ${ }^{5}$ Aarbus University, Højbjerg, Denmark
}

The Late Glacial, that is the period from the first pronounced warming after the Last Glacial Maximum to the beginning of the Holocene (c. 16,000-11,700 cal BP), is traditionally viewed as a time when northern Europe was being recolonized and Late Palaeolithic cultures diversified. These cultures are characterized by particular artefact types, or the co-occurrence or specific relative frequencies of these. In north-eastern Europe, numerous cultures have been proposed on the basis of supposedly different tanged points. This practice of naming new cultural units based on these perceived differences has been repeatedly critiqued, but robust alternatives have rarely been offered. Here, we review the taxonomic landscape of Late Palaeolithic large tanged point cultures in eastern Europe as currently envisaged, which leads us to be cautious about the epistemological validity of many of the constituent groups. This, in turn, motivates us to investigate the key artefact class, the large tanged point, using geometric morphometric methods. Using these methods, we show that distinct groups are difficult to recognize, with major implications for our understanding of patterns and processes of culture change in this period in north-eastern Europe and perhaps elsewhere.

Keywords: Late Palaeolithic, research history, geometric morphometrics, eastern Europe, cultural taxonomies, large tanged points

\section{INTRODUCTION}

During the Last Glacial Maximum (LGM), around 22,000 years ago, the higher latitudes of Europe were devoid of people. When pronounced warming began around 16,000 years ago, groups belonging to the
Magdalenian and Epigravettian traditions began to move northwards (Gamble et al., 2005; Riede, 2014; Wygal \& Heidenreich, 2014). During this colonization, groups occupying particular regions began to develop consistent differences in their material culture, characterized by shouldered 
points (the Creswellian and Hamburgian: Burdukiewicz, 1986), backed points (the Federmessergruppen/Azilian: Schild, 1996), large tanged points (the Bromme culture and others, see below: Ekholm, 1926; Sinitsyna, 2002), and small tanged points (the Ahrensburgian and Swiderian: Taute, 1968; Kobusiewicz, 2002).

Importantly, these regional cultural entities provide the key framework for inferring patterns and processes of migration, adaptation, and potentially even emerging ethnicity in this period. Once certain cultures and their attendant territories are defined, they can move around, their material culture or economic focus can change, and they can interact with one another. Indeed, without archaeological taxonomies, the goal of understanding such past processes cannot be realized (Roberts \& Vander Linden, 2011). Yet, techno-typological classifications in the European Palaeolithic have been repeatedly critiqued. For the Middle Palaeolithic of Europe and the Near East, the infamous debate between Lewis Binford, François Bordes, and Paul Mellars in the 1960s largely broke with the tradition of casting such archaeological phenomena as ethnic entities; yet a legacy of taxonomic inconsistency still haunts this period (Clark, 1999, 2009; Bisson, 2000; Clark \& Riel-Salvatore, 2006; Shea, 2014). Similarly, a soul-searching debate rocked the Levantine Epipalaeolithic in the 1990s, pitching those who saw material culture variation as reflecting ethnic units (Fellner, 1995; Kaufman, 1995; GoringMorris, 1996; Phillips, 1996) against those who were sceptical of such attributions for epistemological reasons (Clark, 1996) or preferred behavioural ecological explanations (Neeley \& Barton, 1994; Barton \& Neeley, 1996). In addition, it has been remarked in relation to the European and Levantine Middle/Upper Palaeolithic (Felgenhauer, 1996; Tomášková, 2003; Clark \& Riel-
Salvatore, 2006; Shea, 2014), as well as for the Late Palaeolithic in northern Asia (Vasil'ev, 2001), the Upper Volga region (Lisitsyn, 2017), and Lithuania (Ivanovaite \& Riede, 2018) that many, if not most, of the analytical units in use today are beset by mdash;at times subtle, at other times critical-local, regional, and national biases.

In eastern Europe, WyszomirskaWebert (1996: 97) viewed the plethora of cultural units with a critical eye, enquiring into the ontological and epistemological robusticity as well as the anthropological meaning of 'all these fantastic cultures' that, according to the then-prevalent view, populated the region in prehistory. As a subset of these, the Late Palaeolithic is made up of several large tanged point cultures, each with a rich and mixed research history. The iconic large tanged point forms, in all its diversity (Figure 1), the basis of cultural classifications. Today, the proposed cultural geography for this period is characterized by substantial taxonomic diversity (Table 1). These groups are traditionally used to infer processes of 'palaeohistory' (sensu Kozłowski \& Kozłowski, 1979): the territories, collective actions, and migrations of identityconscious ethnic groups (Figure 2).

As elsewhere, these projectile points are invested with chronological, spatial, and, by extension, cultural specificity (O'Brien \& Lyman, 1999). Otte \& Keeley (1990) have noted, however, that taxonomic units in this period are usually based on early antiquarian excavations of but a few key sites, reflected in the practice of naming them after these loci classici; they also point out that 'explanations offered for the events in such sequences, whether explicit or implicit, tend to focus on local phenomena or events and reinforce ideas of local continuity and evolution' (Otte \& Keeley, 1990: 577). A more acerbic critique has been voiced by Houtsma and collegues, who argued that '[o]nly when researchers of the Late Palaeolithic 


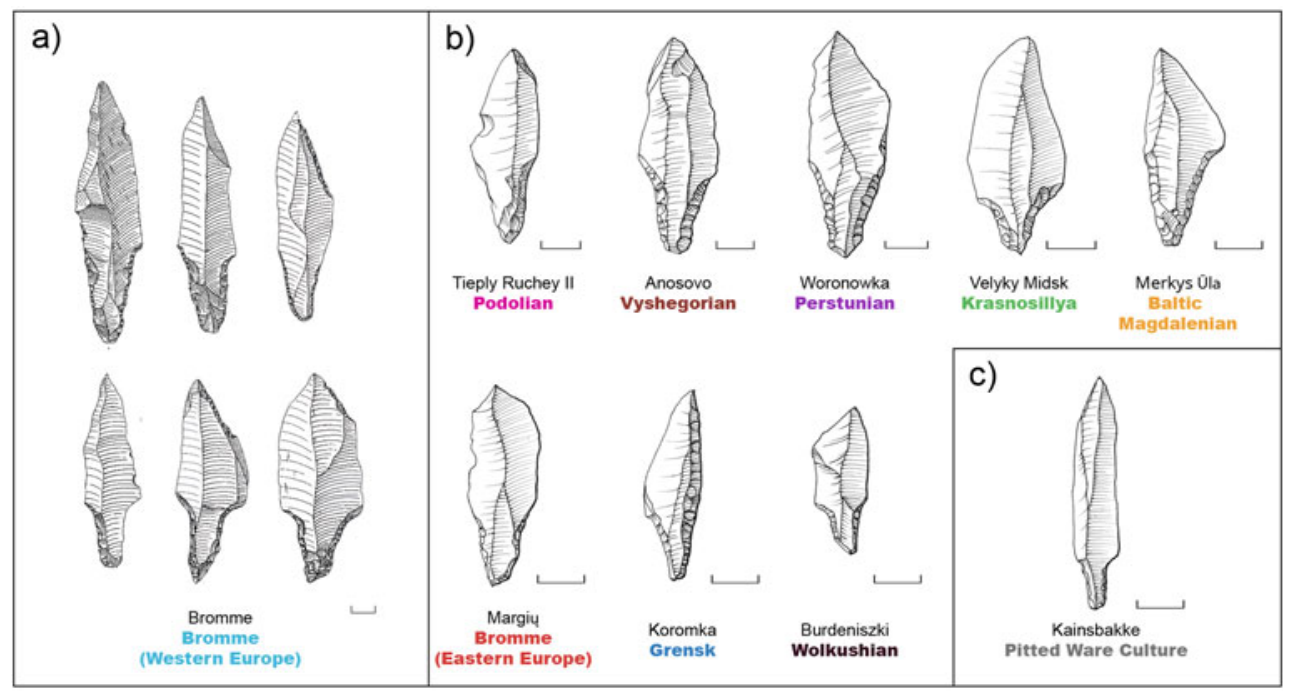

Figure 1. Examples of tanged points from eastern Europe. a) Examples from the type site of Bromme (Denmark). b) Archaeological units in eastern Europe featuring tanged points. c) Examples of tanged points from the Pitted Ware site of Kainsbakke (Denmark). Scale: $10 \mathrm{~mm}$. The colour palette corresponds to the visualization used throughout this article. Illustrations: Bromme (Redrawn after Taute, 1968; Fig. 95: 2, 3, 4, 7, 8, 10), Tieply Ruchey II (Sorokin, 2009; Fig. 3:1), Anosovo (Zaliznyak, 1999; Fig. 31: 2), Woronowka (Redrawn after Szymczak, 1991; Fig. 18:1), Velyky Midsk (Redrawn after Zaliznyak, 1999; Fig. 12:3), Merkys-Üla (Redrawn after Rimantiene, 1971; Fig. 19:5), Margiu (Redrawn after Rimantiene, 1999: Fig. 19:13), Koromka (Redrawn after Zaliznyak, 1999; Fig. 28:29), Burdeniszki (Redrawn after Szymczak, 1995; Fig. 6:2), Kainsbakke (Redrawn after Rasmussen E Richter, 1991; Fig. 21:2).

habitation of the Northwest European Plain escape the constraints of contemporary national borders and the paradigmatic straight-jackets of provincialism and regional chauvinism, which lead to insularity, will we be in a position to gain analytical control of the totality of extant data partitioned into uniform and mutually comparable sets of demonstrably relevant attributes' (Houtsma et al., 1996: 143). Their critique is arguably as valid for the eastern extension of the North European Plain as it is for its western end. Most radically, Clark and Lindly (1991) have argued that this entire way of thinking in terms of archaeological cultures supposedly reflecting past peoples, their actions, adaptations, and migrations is flawed at the paradigmatic level.

In order to bring some clarity to this situation, we present a review of the research history of the Late Palaeolithic large tanged point cultures in eastern Europe. Following Sauer and Riede (2019), such source-critical interrogations provide evaluations of the epistemic status of the units in question. We find many units problematic in this regard and, using geometric morphometric (GMM) approaches, we offer an alternative way of capturing tanged point variability across the region without abstraction from the evidence base.

\section{Research History and Current Late Palaeolithic Cultural Taxonomies: SplitTers $v s$ Lumpers}

In the European Late Palaeolithic, we encounter the lumper-splitter conundrum, well-known from any discipline concerned 
Table 1. Eastern European tanged point cultures, their characteristics and key references.

\begin{tabular}{|c|c|c|c|c|c|}
\hline Culture & Key characteristics & Relation to other cultures & Region & $\begin{array}{l}\text { Presumed } \\
\text { chronology }\end{array}$ & Literature \\
\hline $\begin{array}{l}\text { Baltic } \\
\text { Magdalenian | } \\
\text { Vilnius Group }\end{array}$ & $\begin{array}{l}\text { Single-platform cores, some double-platform } \\
\text { cores; short and broad scrapers; varied } \\
\text { burin types; combination tools (e.g. scra- } \\
\text { pers-burins); 'Bromme-like' points; } \\
\text { 'Ahrensburgian-like' points; tanged points } \\
\text { with complete retouch along one edge; } \\
\text { lance-shaped blades with retouched tips }\end{array}$ & $\begin{array}{l}\text { Elements of both Bromme and } \\
\text { Ahrensburgian; rooted in the Magdalenian }\end{array}$ & Lithuania & $\begin{array}{l}\text { End of } \\
\text { Allerød-Younger } \\
\text { Dryas }\end{array}$ & $\begin{array}{l}\text { Rimantienè, } 1971 \\
\quad \text { Sinitsyna, } 2002\end{array}$ \\
\hline Grensk | Desna & $\begin{array}{l}\text { Conical double-platform cores; end- and } \\
\text { rounded scrapers; various burins; symmet- } \\
\text { ric and asymmetric tanged points with } \\
\text { complete retouch along one edge (some- } \\
\text { times along the entire perimeter) }\end{array}$ & $\begin{array}{l}\text { Two different theories exist regarding the } \\
\text { Grensk culture: autochthonous culture } \\
\text { developed from the Epigravettian vs migra- } \\
\text { tion rooted in Bromme culture }\end{array}$ & Belarus & $\begin{array}{l}\text { Allerød-Early } \\
\text { Holocene }\end{array}$ & $\begin{array}{l}\text { Bud'ko, 1966; } \\
\text { Kozłowski, } \\
\text { 1991; Kolasau, } \\
2018\end{array}$ \\
\hline $\begin{array}{l}\text { Krasnosillya | } \\
\text { North } \\
\text { Ukrainian }\end{array}$ & $\begin{array}{l}\text { Single-platform cores; poorly developed flint } \\
\text { flaking techniques; shortened proportions } \\
\text { of burins and scrapers; tanged points with } \\
\text { steep retouch; crude tanged points; tanged } \\
\text { points featuring oblique truncations; asym- } \\
\text { metric tanged points with complete } \\
\text { retouch along one edge }\end{array}$ & $\begin{array}{l}\text { Viewed as the eastern variant of the } \\
\text { Ahrensburgian; early stage contains 'Lyngby' } \\
\text { elements; origin linked to 'Lyngby' migra- } \\
\text { tion into the Vistula, Nemunas, Pripet, and } \\
\text { Upper Dnieper basins }\end{array}$ & $\begin{array}{l}\text { Present in the } \\
\text { Nemunas and Upper } \\
\text { Dnieper basins, and } \\
\text { in the Polesya region } \\
\text { of Ukraine }\end{array}$ & $\begin{array}{l}\text { End of Allerød- } \\
\text { Younger Dryas }\end{array}$ & $\begin{array}{l}\text { Zaliznyak, 1999; } \\
\quad \text { Sinitsyna, } 2002\end{array}$ \\
\hline Perstunian & $\begin{array}{l}\text { Single- and double-platform cores; burin } \\
\text { variations; end-scrapers; microretouched } \\
\text { blade truncations; Kaszety points }\end{array}$ & $\begin{array}{l}\text { Contemporaneous with the Bromme culture; } \\
\text { together they form the belt of tanged } \\
\text { point cultures along the southern part of } \\
\text { the Baltic sea zone }\end{array}$ & $\begin{array}{l}\text { North-eastern Poland, } \\
\text { Southern Lithuania }\end{array}$ & Allerød & Szymczak, 1987 \\
\hline Podolian & $\begin{array}{l}\text { Single- and double-platform cores; Lyngby } \\
\text { points; burin variations; end-scrapers }\end{array}$ & $\begin{array}{l}\text { Related to the Bromme/Lyngby cultural trad- } \\
\text { ition, reflecting a 'Bromme' migration into } \\
\text { eastern Europe }\end{array}$ & $\begin{array}{l}\text { Upper Volga region, } \\
\text { Russia }\end{array}$ & $\begin{array}{l}\text { Allerød-Younger } \\
\text { Dryas }\end{array}$ & $\begin{array}{l}\text { Sinitsyna, 2002, } \\
2004\end{array}$ \\
\hline Vyshegorian & $\begin{array}{l}\text { Conical, wedge-shaped, and prismatic cores; } \\
\text { end-scrapers (including double end-scra- } \\
\text { pers); various burins; notched tools on }\end{array}$ & $\begin{array}{l}\text { Autochthonous culture developed from an } \\
\text { Epigravettian substrate }\end{array}$ & $\begin{array}{l}\text { Upper Dnieper region, } \\
\text { Russia }\end{array}$ & $\begin{array}{l}\text { Bølling-Younger } \\
\text { Dryas }\end{array}$ & $\begin{array}{l}\text { Sinitsyna, 2002, } \\
\text { 2004, } 2013\end{array}$ \\
\hline
\end{tabular}
pers); various burins; notched tools on blades/bladelets; tanged points similar to Lyngby and Swiderian; shouldered points with lateral retouch 


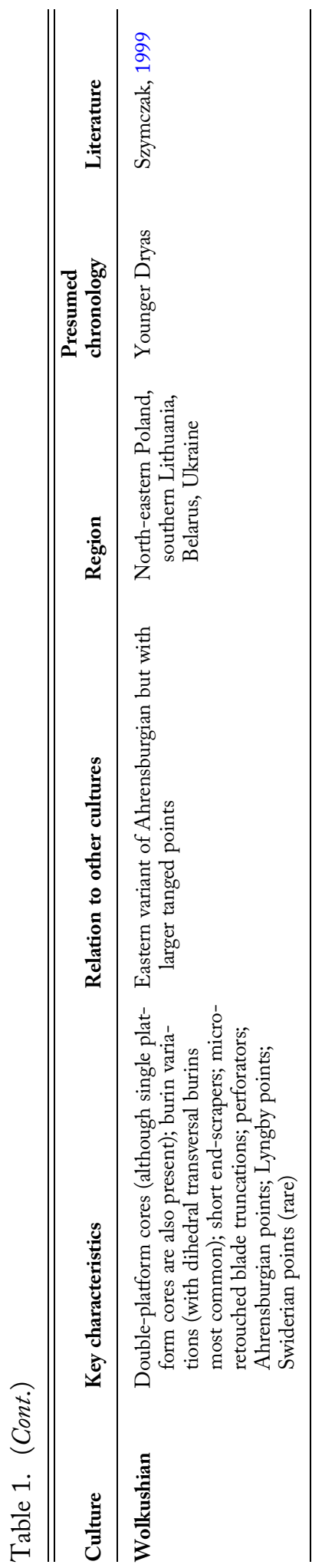

with classification (see Simpson, 1945; Adams \& Adams, 1991): some researchers tend towards lumping assemblages into higher-level units, while others split them in order to distinguish industries, cultures, or facies according to, for instance, local manufacturing traditions or different economic strategies. There are, however, no recognized standards for such classification in archaeology.

Practitioners working within the Palaeolithic archaeological traditions of central and eastern Europe tend to exhibit a strong preference for splitting. Perceived differences between assemblages with large tanged points found in different regions or even in individual river valleys are commonly emphasized. This predilection may stem from the need to organize large quantities of archaeological material from several different countries (e.g. Poland, Lithuania, Russia, Belarus, and Ukraine), coupled with strong regional identities and the, implicit or explicit, motivation to stress differences rather than similarities between regions. Hence, a plethora of cultures considered taxonomically comparable to the Scandinavian Bromme culture are found in eastern Europe, although the criteria for distinguishing these units often remain ambiguous (Table 1).

The explanations for the presence of tanged points in eastern Europe can be divided into three schools:

- direct migration/expansion of the Bromme culture

- cultural contact/diffusion of point forms through borrowing, or

- one or several independent innovations converging on the same form of projectile point.

In Polish Late Palaeolithic archaeology, two particular units are seen as similar to the Brommean in terms of chronology and lithics: the Perstunian (Szymczak, 1991) and Wolkushian cultures (Szymczak, 

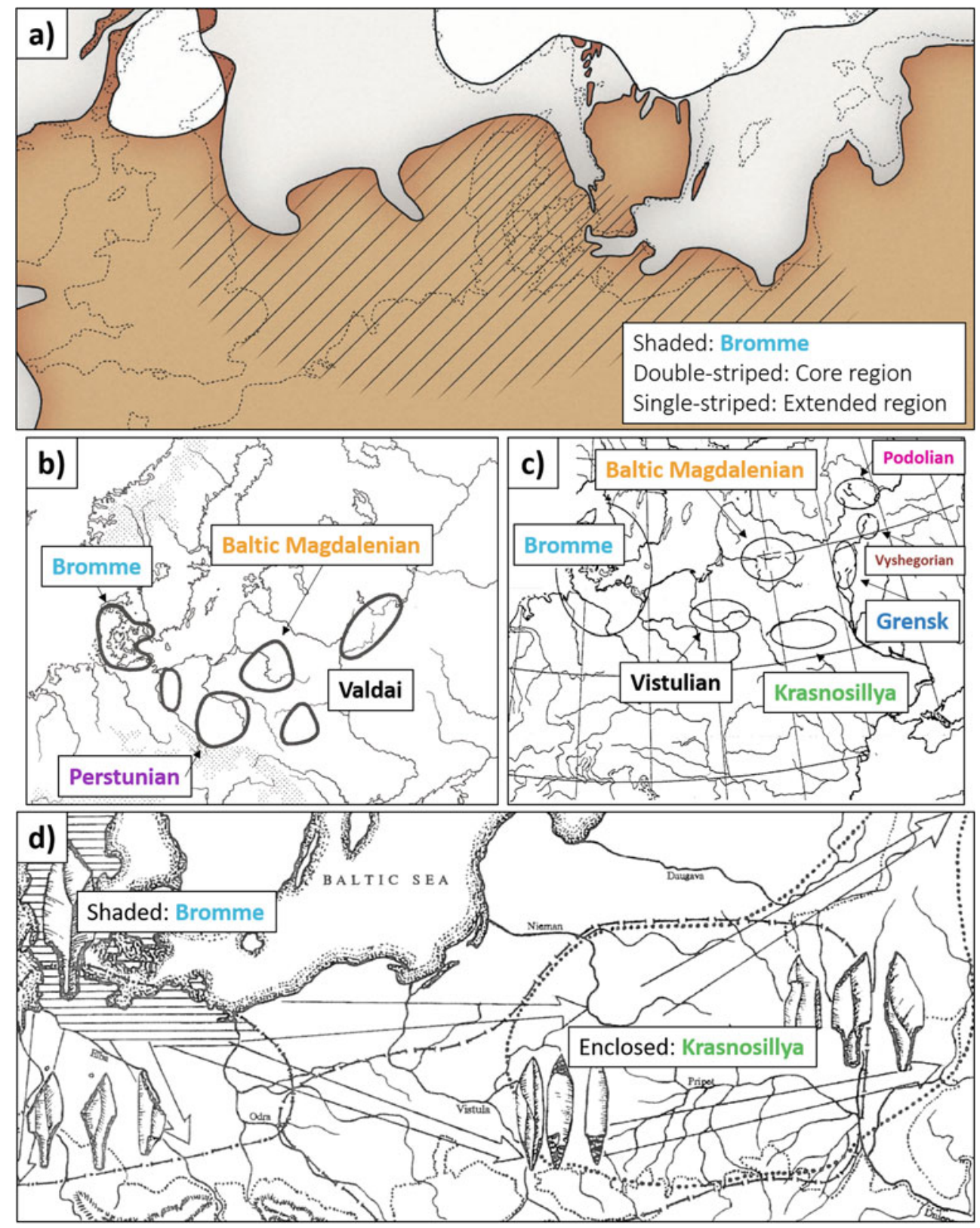

Figure 2. Maps showing the proposed tanged point cultures of north-eastern Europe, from (a) Andersson et al. (2004), (b) Koztowski (1999), (c) Sinitsyna (2002), and (d) Zaliznyak (1999). The colour palette for cultures corresponds to the visualization used throughout this article. Note how the variable taxonomy and the different authors' predilections for splitting or lumping create substantially different cartographic expressions. Common to all these maps is that the relationship between the proposed 'territories' of these large tanged point groups and the evidence on which these are based remains opaque. 
1995). Szymczak (1983, 1987, 1990) distinguished the Perstunian on the basis of six homogeneous sites found in northeastern Poland and southern Lithuania (Szymczak, 1991), but was met with harsh source-critical scepticism at the time (Sulgostowska, 1989).

The Perstunian is explicitly framed as analogous to the Bromme culture in terms of dating and diagnostic tool forms. The Perstunian lithic inventory consists of conical cores, burins, scrapers, and large tanged points, with its origin in the Allerød chronozone. In the absence of absolute dates and meaningful stratigraphies, however, this dating remains a hypothesis grounded in the observation that Perstunian artefacts are typically in worse condition than Swiderian artefacts and the rationale that the eastern European Perstunian assemblages and more westerly inventories of the Bromme culture are generally similar in terms of typology and technology (Szymczak, 1992, 1995). According to Szymczak (1991), the differences between the Perstunian and Brommean are the appearance of doubleplatform cores, a higher frequency of burins, and the appearance of the so-called Kaszety point. Despite the early critique highlighting the weak empirical basis for the Perstunian, this culture has found its way into current literature with sites both in Poland and elsewhere being attributed to it (Siemaszko, 1999a, 1999b; Sinitsyna, 2002).

Likewise, Szymczak also identified the Wolkushian as a separate cultural unit (Szymczak, 1995). The territory of the Wolkushian overlaps with that of the Perstunian, as artefacts of both units are found at the same sites (Szymczak, 1995). Wolkushian lithic tool forms are also similar to the Perstunian with single- and double-platform blade cores, and varying forms of scrapers, burins, and tanged points. For Szymczak (1995), the distinctive features of the Wolkushian include: a high frequency of double-platform cores, large core-like burins, large tanged points including forms with flat ventral retouch reminiscent of the Swiderian, large tanged points with no ventral retouch analogous to Brommean points, and smaller tanged points lacking any modifications of the ventral surface similar to Ahrensburgian points (Szymczak, 1995). Wolkushian elements have so far been recognized at nine sites-some seemingly homogenous, some mixed-from north-eastern Poland.

Further to the east, a suite of geographically tightly circumscribed cultures distinguished by large tanged points have been proposed. These are: 1) the Baltic Magdalenian/Vilnius group; 2) the Grensk culture; 3) the Krasnosillya/North Ukrainian group; 4) the Podolian; and 5) the Vyshegorian.

In Lithuania, the Baltic Magdalenian culture was first defined by Rimantiene (1971), who argued that it stemmed from the same Late Magdalenian origin as the Brommean. The tools characterizing this culture are single- and double-platform cores, various tanged point forms, short and broad scrapers, burins of different types, and combination tools. Smaller tanged points, it was argued, are the main difference between the Baltic Magdalenian and the Brommean, which in turn implied a slightly later date for the Lithuanian Late Palaeolithic (Rimantienè, 1971). Later, this culture was rejected by some Lithuanian scholars and replaced with a classification that split the same material (Šatavičius, 2016). A recent review of the evidence has failed to find support for such detailed splitting (Ivanovaite \& Riede, 2018).

In Belarus, many Late Palaeolithic tanged point assemblages are attributed to the Grensk culture first defined by Bud'ko (1966) and argued to reflect a local 
development from eastern Epigravettian traditions. Later, a migration-based theory suggested the introduction of the Bromme/Lyngby culture as the source of this regional development (Zaliznyak, 1999). These two explanations continue to exist as the favoured, albeit opposing, hypotheses for the origin of the Grensk phenomenon (see Kolasau, 2018). Typical Grensk assemblages consist of single-platform and double-platform cores, although other (multiple platform and discoidal) forms are also found; various forms of scraper occur, as do truncated, dihedral, angle, and combination burins, notched tools, borers, flakes with obliquely retouched truncation, backed blades, and chopping tools. Tanged points and specifically asymmetrical points termed the 'Grensk type' characterize the eponymous assemblages (Kolasau, 2018).

In the Polesia region of Ukraine, the Krasnosillya culture was first distinguished by Zaliznyak (1999), one of the main advocates of Bromme/Lyngby migrations from Scandinavia to eastern Europe. To him, this migration was the source for all eastern European tanged point cultures. A typical trait of Krasnosillya lithic technology is its low tool-blank selectivity. Tools are mainly formed by intensive retouching of ad hoc blanks rather than standardized blades (Zaliznyak, 1999). These assemblages comprise mainly single-platform cores, in addition to burins and tanged points of variable size (Zaliznyak, 1999).

In Russia, two pertinent archaeological cultures are identified, the Podolian of the Upper Volga region and the Vyshegorian of the Upper Dnieper Basin, with both autochthonous and migration theories proposed to understand them (Sinitsyna, 2002, 2004). The Podolian is viewed as a Brommean analogue resulting from earlier dispersals (Sinitsyna, 2002, 2004). Characteristic lithics include single- and double-platform cores, large tanged points, burins made from broken tanged points, various scrapers, and axes produced from flakes. The Vyshegorian, in contrast, represents an autochthonous development from the Epigravettian (Sinitsyna, 2013). Typical assemblages include conical, wedge-shaped single- and double-platform prismatic cores, tanged and shouldered points with lateral retouch, various burin types, scrapers, notched tools, and axes (Sinitsyna, 2002, 2004). Like most Late Palaeolithic cultures in eastern Europe, these two cultures are poorly defined chronologically. While the Podolian is dated to the Allerød/Younger Dryas through typological and geological inference, a single relevant radiocarbon date (LE-5029) places it at $9180 \pm 75$ BP (Sinitsyna, 2004). Calibrated with OxCal 4.3 (Bronk Ramsey, 2009) and using the IntCal 13 calibration curve (Reimer et al., 2013), this yields an early Holocene date of 10,550-10,220 cal вP.

Kobusiewicz (2009a, 2009b) has argued that the various proposed eastern European cultures identified in the basis of large tanged points are epistemologically weak because:

1. these cultures are often based on limited material derived from poorly constrained assemblages

2. large tanged points most commonly occur with other elements (e.g. archbacked points, small tanged points) argued to be indicative of other cultures

3. the size of the proposed territories does not correspond to meaningful territorial sizes observed in the ethnographic record (see Sauer \& Riede, 2019), and

4. the argued differences in the shape of the diagnostic artefacts are too slight.

Following up on this critique, Sauer and Riede (2019) have also shown that artefact frequencies, used in the Bordian tradition as a cultural designator (see Salomonsson, 
1964; Kozłowski \& Kozłowski, 1979), do not yield meaningful results, especially when formal types are few and ambiguous and assemblages are most commonly derived from surface collections. Contemporaneous osseous artefacts or other non-lithic elements are exceedingly rare and hence play a very limited role in cultural taxonomy, leaving the supposedly diagnostic projectile point forms as the foundation of contemporary cultural taxonomies. All this makes it a pressing matter to examine the large tanged points of eastern Europe, with the aim of revealing shape variations that are structured temporally and/or spatially. In the following, we build on earlier GMM analyses of tanged points in northern Europe (Serwatka \& Riede, 2016; Serwatka, 2018), but with a specific focus on eastern Europe and with a particular aim to uncover, if possible, meaningful hierarchical structure within this key artefact class.

\section{Materials ANd Methods}

To investigate the appropriateness of the current nomenclature used throughout the Late Palaeolithic of eastern Europe, a twodimensional GMM methodology is used here, drawing on illustrations of 177 complete tanged points from seventy-two archaeological contexts, distributed across sixty-one sites. Examples come from Poland, Belarus, Lithuania, western Russia, and Ukraine (Figure 3), and include cultural taxonomic attributions to the Baltic Magdalenian, Bromme, Grensk, Krasnosillya, Perstunian, Podolian, Vyshegorian, and Wolkushian units. This is complemented by examples of the Bromme culture from western Europe $(n=49)$, including specimens from the eponymous Bromme site (Mathiassen, 1946), and, as a control group, mid-Holocene 'Type A' large tanged points from the Pitted Ware culture $(n=24)$ which infamously resemble Late Palaeolithic specimens (Fischer, 1985). Therefore, a total of 250 lithic illustrations were examined (Table 2). We are aware that the size of this sample is limited, but it does reflect the truly limited selection of artefacts on which some of the cultural taxonomic units are based and the fact that we restricted our sample to complete specimens. While any statistical approach should work with as large a sample size as possible, we note that the use of lithic drawings, as presented by their authors, does allow testing of cultural taxonomic assessments because complete and supposedly typical or ideal specimens are usually selected for drawing with the strong epistemic implication that they are representative of taxonomic entities in general (see Lopes, 2009). One implication of this original selection bias inherent in the literature is that our analysis probably addresses merely a fraction of the actual lithic variability found in the Late Palaeolithic in the region, but stands as a direct cultural taxonomic test visa-vis the existing corpus of literature.

To examine shape variation among these specimens and taxonomic units, elliptic Fourier analysis (EFA) was used. EFA is a method of closed-outline shape analysis grounded on the decomposition of closed outlines (produced through the creation of semi-landmarks) into an infinite series of repeating trigonometric functions (harmonics; see Caple et al., 2017). EFA has the advantage of not requiring data points to be equal in number, or evenly spaced, allowing more closely-spaced data points on segments of high curvature and artefact complexity (Rohlf \& Archie, 1984; Crampton, 1995). EFA is now commonplace in the exploratory and statistical analysis of archaeological stone tool shapes (Gero \& Mazzullo, 1984; Saragusti et al., 2005; Iovita, 2009, 2010; Serwatka, 2015; Iovita et al., 2017).

All illustrations (.png) were first synthesized into one thin-plate spline (.tps) file, 


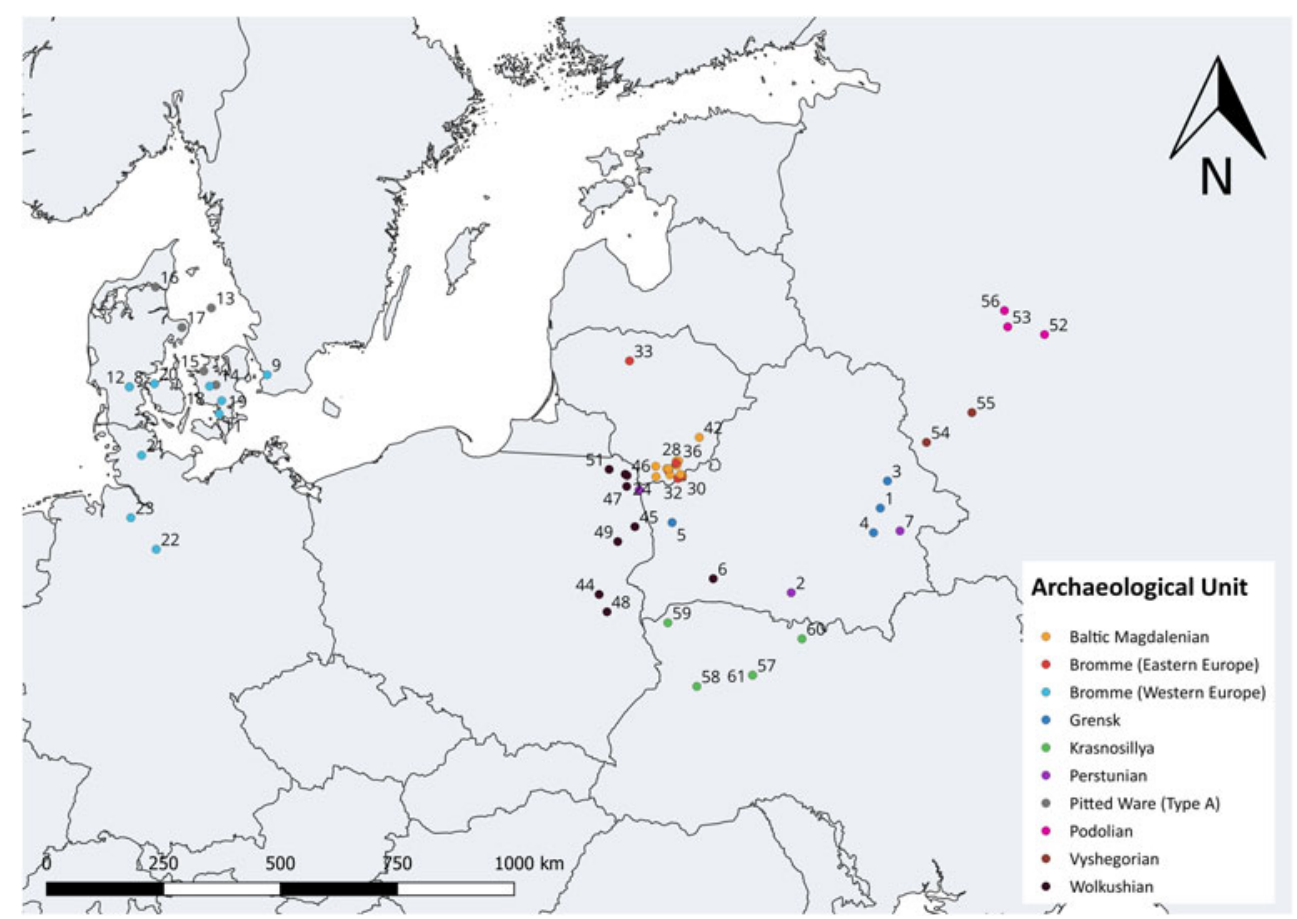

Figure 3. Map of all sites examined in this study. 1) Baroŭka; 2) Chilczyce; 3) Chrojnaja; 4) Koromka; 5) Krasnasielski; 6) Motol; 7) Woronowka; 8) Elemly Sø; 9) Hjarup Mose; 10) Rolykkevej; 11) Rundebakke; 12) Sølystgaard; 13) Anholt; 14) Søtofte; 15) Føllenslev; 16) Smedegaarde; 17) Kainsbakke; 18) Bromme; 19) Trollesgave; 20) Bro; 21) Alt Duvenstedt; 22) Dohnsen; 23) Sassenholz; 24) Baltašiškes; 25) Derežnyčia; 26) Duba; 27) Ežerynas; 28) Glükas; 29) Glyno Pelké; 30) Gribaša; 31) Kašètos; 32) Katra; 33) Lieporiai; 34) Marcinkonys; 35) Margiu; 36) Maskauka; 37) Merkys-Ūla; 38) Mitriskes; 39) Rudnia; 40) Varena; 41) Varene; 42) Vilnius; 43) Burdeniszki: 44) Dziewule-Piaski; 45) Krzemienne; 46) Máckowa Ruda; 47) Płaska; 48) Stánkowicze; 49) Suraż; 50) Wolkusz; 51) Zusno; 52) Podol; 53) Ust-Tudovka; 54) Anosovo; 55) Vishegore; 56) Tieply Ruchey; 57) Krasnosillya; 58) Lipa; 59) Liutka; 60) Rudnya; 61) Velyky Midsk.

a common file format for GMM analyses. This was carried out in tpsUtil v.1.69. Cartesian coordinates and positions for each image were created using the 'Outline object' function in tpsDig2 v.2.27 and pixel noise eliminated in tpsDig2 (Rohlf, 2015). As these outlines do not require the same number of landmarks, and in order to capture as much of the original shape as possible, the raw outline was retained (Figure 4). Thus, the tanged point specimens feature an average of 1544 Cartesian coordinates. In standardizing all outlines prior to EFA, all specimens were normalized to a common centroid $(0,0)$ and rescaled using their centroid size as suggested by Bonhomme et al. (2017). Normalization through rotation was unnecessary as this is incorporated through subsequent elliptic fitting. In selecting an appropriate number of harmonics necessary to capture tanged point shape (here defined as 99.9 per cent harmonic power), the 'calibrate_harmonicpower_efourier' function, supported by the 'calibrate_reconstructions efourier' and 'calibrate_deviations_efourier' functions in Momocs v.1.2.9 (Bonhomme et al., 2014) were used. For 99 per cent harmonic power, eleven harmonics were retained. 
Table 2. Dataset used in this study $(n=250)$.

\begin{tabular}{lr}
\hline Archaeological unit & n \\
\hline Grensk & 55 \\
Baltic Magdalenian & 36 \\
Bromme (western Europe) & 49 \\
Krasnosillya & 29 \\
Pitted Ware (Type A) & 24 \\
Wolkushian & 22 \\
Podolian & 14 \\
Bromme (eastern Europe) & 9 \\
Vyshegorian & 8 \\
Perstunian & 4 \\
\hline
\end{tabular}

To assess the robustness and structure of the current taxonomy, the elliptic Fourier descriptors were first subjected to exploratory principal components analysis (EFA-PCA), an ordination-based method for exploring the underlying shape structure within a GMM dataset. In visualizing differences and similarities among different archaeological units, 66 per cent confidence ellipses are employed. The contributions of each major principal axis were examined through a scree plot, along with the specific XY shape transformations and configurations. Discrimination-based analyses were not undertaken as a number of groups do not meet suggested sample size values and as our a priori confidence in the groups' validity is low, given the research-historical and epistemic concerns outlined above. Such concerns make discriminant analyses unsuitable as a test of taxonomic validity (Klecka, 1980; McGarigal et al., 2000; Kovarovic et al., 2011). To explore tanged point variation between different archaeological units through a statistical framework, a multivariate analysis of variance (MANOVA), through a Hotelling-Lawley, of 99 per cent cumulative shape variance (the first twenty-one principal components) was carried out. If significant, pairwise testing (through a Pillai Trace) is employed to understand the relationship between specific archaeological units. Statistical significance is defined here by an alpha level of 0.01 , with a null hypothesis of no difference between taxonomic units.

Finally, to better understand the underlying structure and degree of similarity among archaeological units, agglomerative hierarchical cluster analysis was adopted. Agglomerative hierarchical clustering works on dissimilarity matrices and builds a hierarchical structure from individual shapes by progressively merging clusters (Shennan, 1997; Claude, 2008). Here, agglomerative hierarchical clustering (complete linking) is employed to visualize, quantify, and hence qualify the degree of dissimilarity between all artefacts in relation to their proposed archaeological unit membership. A dendrogram using the first twenty-two principal components and a Euclidean distance measure is employed here.

All analyses were carried out in Momocs v.1.2.9 (Bonhomme et al., 2014) for the R Environment ( $\mathrm{R}$ Development Core Team, 2017). Complementary R packages including tidyverse v.1.2.1 (https://cran.r-project.org/web/packages/ tidyverse/index.html and ggtree v.10.5, Yu et al., 2017) were used for data visualization and transformation. The Open Science guidelines from Marwick (2017) were followed and the .tps file, the metadata, and annotated R script can be found on the Open Science Framework (https:// osf.io/agrwb/). All associated code, data, and figures can also be found on GitHub: https://github.com/CSHoggard/-EasternEurope-Tanged-Points.

\section{Results}

An examination of tanged point outline shape through EFA-PCA reveals that the first three principal components feature 

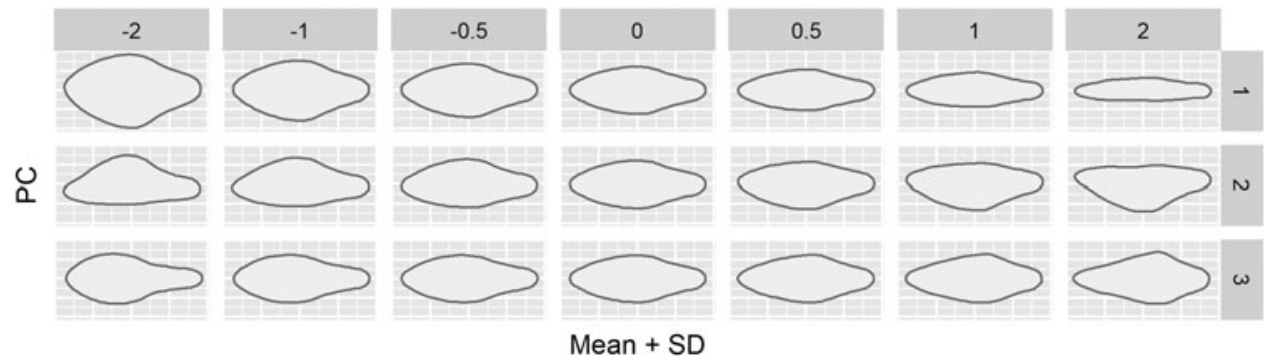

Figure 4. XY transformations for the first three principal components $(82.1$ per cent cumulative shape variance).

greater than 5 per cent shape variance, and total 82.1 per cent cumulative shape variance. The first principal component (57.7 per cent shape variance) ranges from tanged points with narrow tangs, shoulders, and blade edges to wider forms, whereas the second principal component (16.4 per cent shape variance) represents an asymmetric transformation, specifically the positioning of the shoulder or blade edge with the greatest convexity. The third principal component (8.0 per cent shape variance) extends from elongated to short and wider tang forms. For a visual guide to these first three principal components see Figure 4, and for further information on the transformations of subsequent principal components please refer to the $\mathrm{R}$ script noted above (https:// osf.io/agrwb/).

When the shape variation is explored through the different archaeological units, the PCA analysis (Figure 5) highlights the difficulty in classifying certain archaeological units by tanged point shape, and, conversely, in distinguishing between specific units. In the first principal component, Podolian, Grensk, and Vyshegorian groups occupy a similar morphospace (their confidence ellipses overlap) with negative PC1 scores indicative of wider tanged forms. In contrast, Pitted Ware examples have the greatest proportion of positive PC1 scores indicative of slender tanged forms, to an extent where there is little overlap with other archaeological units. In the graph centroid (shapes more typical of the mean), several overlapping units can be observed, including the Wolkushian, Bromme (both regions), Krasnosillya, and Baltic Magdalenian. This overlap largely continues into the second principal component, with these same units overlapping.

Regarding the second and third principal components, considerably greater variation is exhibited in many of the archaeological units, with the Perstunian and Pitted Ware examples most strongly constrained. As the second principal component represents asymmetric variation in the accentuation of the tang, dorsal/ventral siding may help explain this great variation. The first and third principal components may better represent the actual variation exhibited by the archaeological units, as these represent symmetric changes in tanged point shape. However, the distribution of artefacts in this plot largely mirrors the first plot, with a distinct Pitted Ware cluster, similarities in Podolian, Vyshegorian, and Grensk forms, and a mixture of units in the graph centroid.

With 99 per cent cumulative shape variance, a MANOVA was carried out and highlighted statistical significance to the desired 0.01 alpha level (Hotelling-Lawley: 

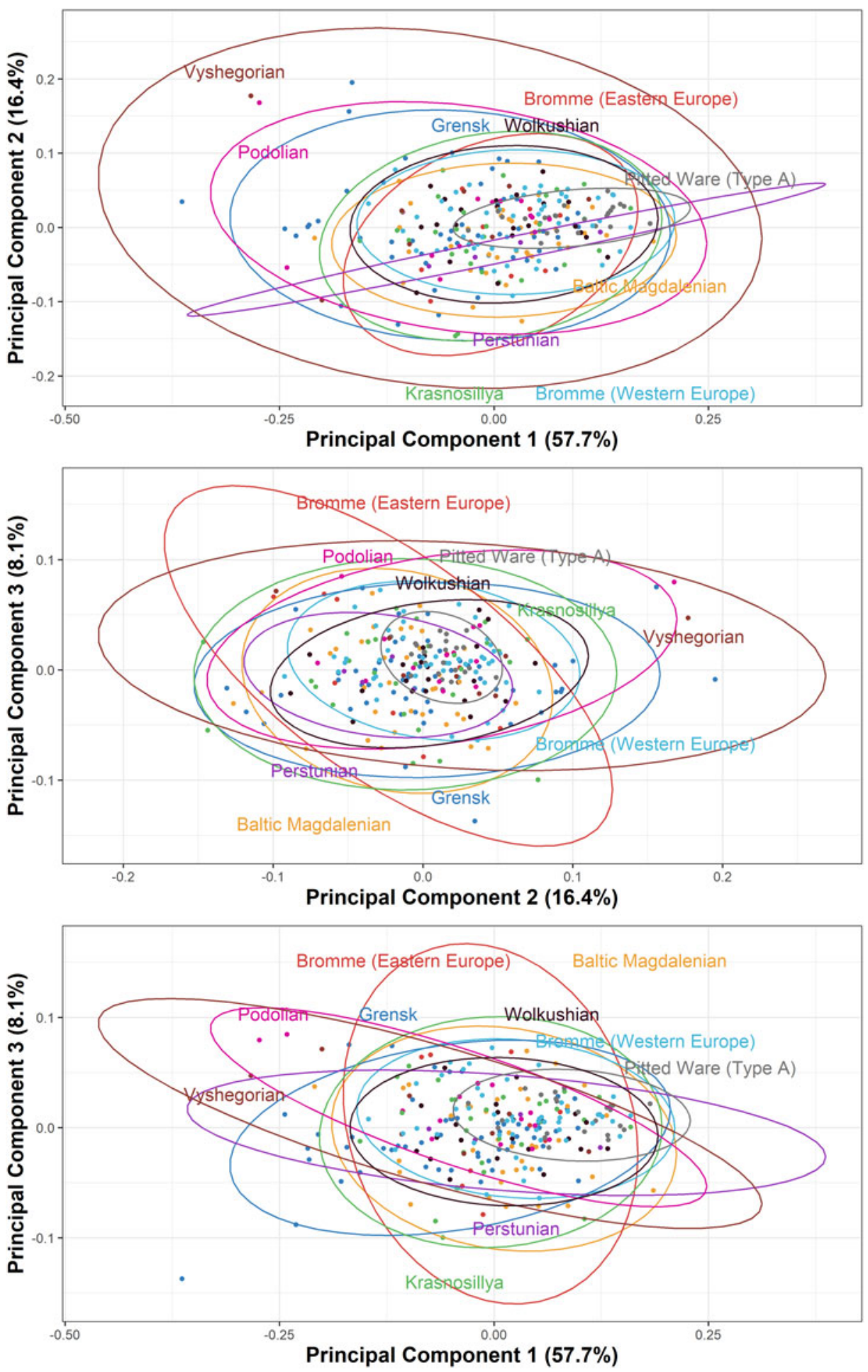

Figure 5. Principal component analysis of Fourier coefficients calculated for Late Palaeolithic tanged points in eastern Europe. Top: PC1 and PC2 (74.1 per cent cumulative variance). Middle: PC2 and PC3 (24.46 per cent cumulative variance). Bottom: PC1 and PC3 (66.3 per cent cumulative variance). 
1.7604, F: 2.0326, $p$ : < 0.0001), demonstrating difference in artefact shape among all tanged points. Given the significance of the overall test, further tests for pairwise differences were undertaken (Table 3). In this, differences can be observed, specifically differences between: 1) Pitted Ware (Type A) and all other taxonomic units; 2) the Baltic Magdalenian and Bromme (western European) units; 3) the Grensk and Bromme (western European) units; 4) the Grensk and Krasnosillya units; and 5) the Grensk and Wolkushian units. Interestingly, no statistical difference was observed between the two Bromme units (Pillai Trace: 0.1073, F: 1.5931, $p:$ 0.1897), indicating no difference in artefact shape; no difference between Bromme examples in eastern Europe and any other eastern European unit was also detected (see Table 3). The consistently identified difference between the putative Late Glacial cultural units identified by large tanged points and the much later Pitted Ware culture points is notable and encouraging. Pitted Ware culture points tend to be more symmetric than Late Palaeolithic specimens (Dev \& Riede, 2012) and are more likely to have been arrowheads (Bye-Jensen, 2011), whereas earlier large tanged points are more probably dart-points (Riede, 2009). The ballistic form and size constraints on dart-heads are somewhat laxer compared to arrowheads (see Shott, 1997) and this appears to be reflected in the consistently narrow shape of our Pitted Ware specimens.

A hierarchical cluster analysis of all individual tanged points (Figure 6) indicates that very few of the artefacts assigned to the different archaeological units demonstrate consistent grouping. Some sites show minor clustering, such as Koromka (artefact IDs 63-68), perhaps indicative of locally or individually shared behaviour. Yet, on a higher branch level, no clustering consistent with traditional cultural

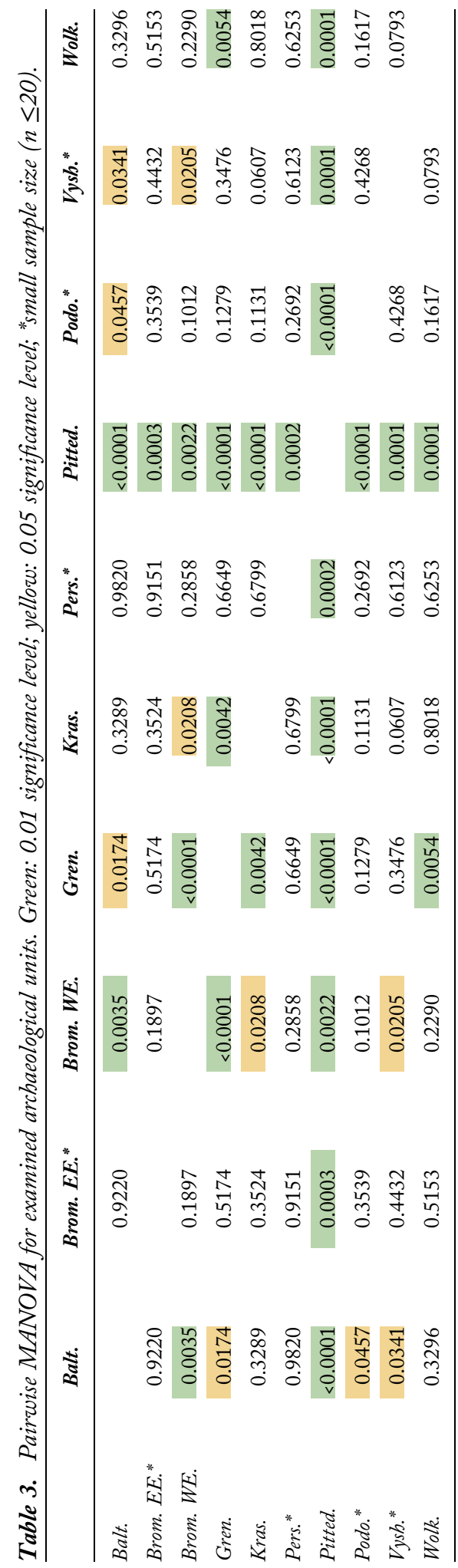




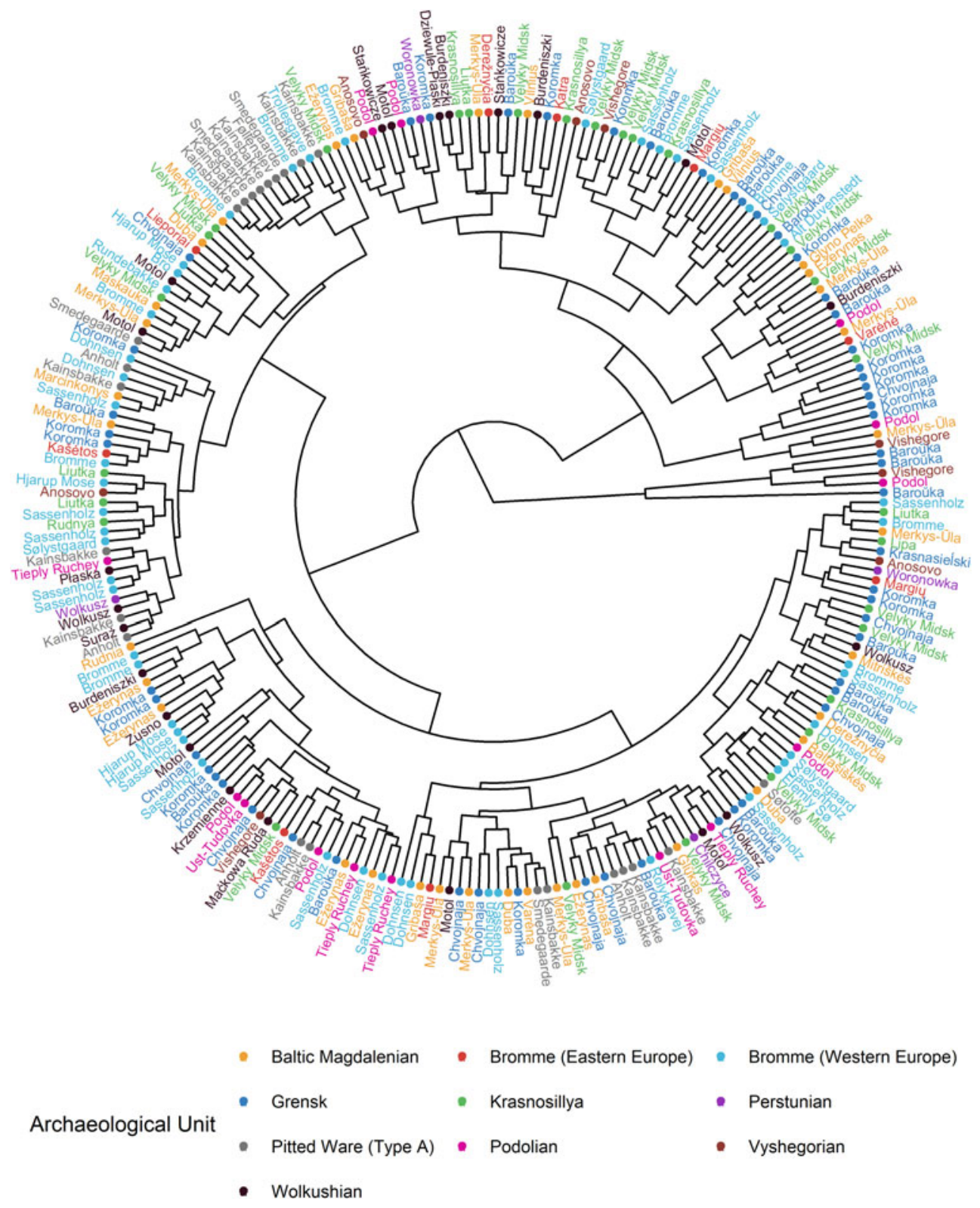

Figure 6. Hierarchical agglomerative clustering (complete linkage) of all tanged point outlines $(n=250)$ and their associated taxonomic unit (IDs correspond to the dataset associated with this article).

taxonomic units is observed. The sole exception is the Pitted Ware culture (Type A), with the majority of specimens clustering within one or two clades, further highlighting the degree of standardization in this specific tanged point.

\section{Discussion}

Ethnographic observations of group identity encoded in lithic projectile points (e.g. Wiessner, 1983; Sinopoli, 1991) are often cited as the core rationale for 
grounding Palaeolithic cultural taxonomies on this artefact. In the Late Palaeolithic of Europe, projectile points are also, implicitly or explicitly, taken to be the primary artefact class defining cultural groupings. Yet, our investigations into research history and the GMM analyses reported here indicate that existing classifications of the Late Palaeolithic cultures anchored in lithic projectile point forms in northeastern Europe at least are not robust. It appears that there are no consistent differences in projectile point shape between the various cultures as currently proposed. In sum, the diverse and highly variable morphologies of large tanged projectile points found in the region prevents any robust classification of this material and hence makes building larger-scale cultural taxonomies difficult - at least those that aim to distinguish regionally or locally circumscribed units on the basis of lithic projectile points.

The general simplicity of form and similarity of Late Palaeolithic tanged points makes it hard to draw any conclusions about intercultural diversity based on this artefact class alone. Notably, simplicity and variability also characterize other aspects of Late Palaeolithic lithic technology, which is straightforward and generic, relying on raw materials of variable quality and rather ad hoc core exploitation strategies, both in the western (Fischer, 1991: 116; Barton, 1992: 192; Madsen, 1992: 128; Johansen, 2000: 22) and eastern parts of northern Europe (Rimantienè, 1971; Szymczak, 1991, 1995; Sinitsyna, 2002). Although we did not analyse other tool, blade, or core forms at the same level of detail, our review of these elements commonly used as classificatory auxiliaries also shows substantial overlap between units.

Whether this overall similarity in Late Palaeolithic technology and artefact shapes is primarily caused by shared ancestry or whether it suggests a substantial degree of convergent technological evolution (O’Brien et al., 2018) remains to be investigated in greater detail. Recent genomic studies are revising migrantionist theories. Villalba-Mouco et al. (2019), for instance, suggest that, by 15,000 years ago, huntergatherers of distinctly different ancestry admixed with and replaced groups associated with the Magdalenian in parts of Europe. While this can be interpreted to indicate that Magdalenian foragers did not reach eastern Europe, as suggested by Rimantiene (1971), and that the Late Palaeolithic colonization of eastern Europe should instead be associated with the Epigravettian, as suggested by Bud'ko (1966), the logic of linking culturally defined groups with genetic clusters itself needs urgent attention (see Riede et al., 2019). The absence of secure radiocarbon dates associated with eastern European tanged point assemblages, as well as the paucity of organic remains including human remains suitable for genomic interrogration, make the matter more complicated by not allowing a secure placement of these assemblages in the wider chronological context of the Late Palaeolithic.

It is our worry that the school of thought that links ethnicity with prehistoric culture history-shown to be prevailing in eastern Europe (Barford, 1996; Wyszomirska-Webert, 1996)—has been driving the profligate definition of Late Palaeolithic cultures; yet they cannot readily be discriminated in a quantitative, inter-regional perspective. Much like the Levantine Epipalaeolithic, Late Palaeolithic Europe may thus be largely populated by 'phantom cultures' (Barton \& Neeley, 1996: 139).

\section{Conclusion}

Cultural taxonomy is as essential to archaeological enquiry as it is unfashionable. 
For most periods of the European Palaeolithic, multiple and sometimes competing cultural taxonomic schemata have been proposed, usually with reference to key artefact classes such as projectile points. Our current taxonomies have accumulated over long periods of changing theoretical, conceptual, and methodological paradigms and in tandem with broader socio-political changes. Most workers are aware of such caveats, yet culturally-laden typological designations are frequently used in archaeological research and heritage management alike, reinforcing the impression of strong regional distinctiveness in the archaeological record (see Barford, 1996; Riede, 2017). The Late Palaeolithic of eastern Europe is no exception, but our critical investigation into research history and novel analyses of tanged point shapes have shown that many currently defined regional groupings are not as diagnostically distinct as previously proposed.

In our analysis, we have focused exclusively on large tanged points. Naturally, other aspects of material culture may allow us to better discriminate between cultural units. In particular, lithic reduction techniques, as analysed through operational chains, have been proposed as a key method (e.g. Damlien et al., 2018). Problematically, however, such time-consuming analyses usually begin by selecting assemblages that are pre-classified by traditional typological means (mostly through projectile points) and hence tend to replicate traditional taxonomies. Furthermore, limited sample sizes and as yet unexamined degrees of inter-observer variability speak against operational chain analysis as necessarily a better way of resolving cultural taxonomic questions. Most probably, a judicious combination of qualitative and quantitative methods will provide the hoped-for solution, although available methodologies (e.g.
Tostevin, 2013) have yet to be applied to the Late Palaeolithic of Europe. By this token, our analysis should be understood as a new parsimonious lumping hypothesis to be tested against alternative definitions using similarly transparent, datadriven approaches.

Nonetheless, it is critical that we clarify these issues and begin to build more robust cultural taxonomies as both palaeoenvironmental scientists and geneticists are increasingly looking to explain Late Pleistocene human demographic processes-and they tend to incorporate archaeologically defined units under the reasonable assumption that these are robust and can be understood as proxies for past populations (see Riede et al., 2019). While we strongly welcome the ambitions and intentions behind such novel bio-cultural approaches, we caution equally strongly against uncritically deploying the cultural taxonomic units of the northern European Late Palaeolithic as they are currently defined. New methods, such as geometric morphometrics, coupled with, for instance, cultural phylogenetics are offering innovative ways to construct archaeological taxonomies. Such cultural phylogenies represent hypotheses of historical patterns and processes (see O'Brien et al., 2008). They can be used to discriminate between divergent and convergent cultural evolution, and they offer ways of more formally and transparently defining nested cultural taxonomies. Future research should seek to include as wide a range of material culture information as possible. The everincreasing availability of literature is facilitating such comparative approaches, yet barriers to inter-regional integration persist. Aligning and opening archaeological datasets across research traditions, as we have attempted here, is a prerequisite for overhauling integrative comparative approaches. 


\section{ACKNOWLEDGments}

Livija Ivanovaite, Christian Hoggard, Florian Sauer, and Felix Riede were supported by grant \#6107-00059B awarded to Felix Riede by the Independent Research Fund Denmark. Kamil Serwatka was supported by the Aarhus University Research Foundation. Felix Riede also gratefully acknowledges funding from the European Research Council (grant agreement 817564 under the Horizon 2020 research and innovation programme). Finally, the authors would like to thank the three anonymous reviewers for their valuable comments and the EJA editorial team's attention to detail.

\section{REFERENCES}

Adams, W.Y. \& Adams, E.W. 1991. Archaeological Typology and Practical Reality: A Dialectical Approach to Artifact Classification and Sorting. Cambridge: Cambridge University Press.

Andersson, M., Karsten, P., Knarrström, B. \& Svensson, M. 2004. Stone Age Scania: Significant Places Dug and Read by Contract Archaeology (Riksantikvarieämbetet Skrifter 52). Lund: Riksantikvarieämbetet.

Barford, P. 1996. Aspects of Cultural Definition in Central European Prehistory. Archaeologia Polona, 34: 33-57.

Barton, C.M. \& Neeley, M.P. 1996. Phantom Cultures of the Levantine Epipaleolithic. Antiquity, 70: 139-47. https://doi.org/10. 1017/S0003598X00082995

Barton, R.N.E. 1992. Hengistbury Head, Dorset. Volume 2: The Late Upper Palaeolithic E Early Mesolitbic Sites. Oxford: Oxford Committee for Archaeology.

Bisson, M.S. 2000. Nineteenth Century Tools for Twenty-first Century Archaeology? Why the Middle Paleolithic Typology of François Bordes Must Be Replaced. Journal of Archaeological Method and Theory, 7: 1-48. https://doi.org/10.1023/a: 1009578011590

Bonhomme, V., Picq, S., Gaucherel, C. \& Claude, J. 2014. Momocs: Outline
Analysis Using R. Journal of Statistical Software, 56: 1-24.

Bonhomme, V., Forster, E., Wallace, M., Stillman, E., Charles, M. \& Jones, G. 2017. Identification of Inter- and Intraspecies Variation in Cereal Grains Through Geometric Morphometric Analysis, and its Resilience under Experimental Charring. Journal of Archaeological Science, 86: 60-67. https://doi.org/10.1016/j.jas. 2017.09.010

Bronk Ramsey, C. 2009. Bayesian Analysis of Radiocarbon Dates. Radiocarbon, 51: 337-60. https://doi.org/10.1017/S0033822200033865

Bud'ko, V.D. 1966. Pamiatniki sviderskogrenskoi kultury na territorii Belorussii. In: $U$ istokov drevnikb kultur. Materialy i issledovaniya po arkheologii SSSR, 126. Moskva-Leningrad: Izdatel'stvo Akademii nauk SSSR, pp. 35-46.

Burdukiewicz, J.M. 1986. The Late Pleistocene Shouldered Point Assemblages in Western Europe. Leiden: Brill.

Bye-Jensen, P. 2011. Eksperimenter med flækkepilespidser. Studier af pilespidser fra grubekeramisk kultur. Kuml, 60: 63-82.

Caple, J., Byrd, J. \& Stephan, C.N. 2017. Elliptical Fourier Analysis: Fundamentals, Applications, and Value for Forensic Anthropology. International Journal of Legal Medicine, 131: 1675-1690. https:// doi.org/10.1007/s00414-017-1555-0

Clark, G.A. 1996. Plus français que les Français. Antiquity, 70: 138-39. https:// doi.org/10.1017/S0003598X00082983

Clark, G.A. 1999. Highly Visible, Curiously Intangible. Science, 283: 2029-32. https:// doi.org/10.1126/science.283.5410.2029

Clark, G.A. 2009. Accidents of History: Conceptual Frameworks in Paleoarchaeology. In: M. Champs \& P. Chauham, eds. Sourcebook of Paleolitbic Transitions. New York: Springer, pp. 19-41.

Clark, G.A. \& Lindly, J.M. 1991. On Paradigmatic Biases and Paleolithic Research Traditions. Current Anthropology, 32: 577-87. https://doi.org/10.1086/204002

Clark, G.A. \& Riel-Salvatore, J. 2006. Observations on Systematics in Paleolithic Archaeology. In: E. Hovers \& S.L. Kuhn, eds. Transitions Before the Transition: Evolution and Stability in the Middle Palaeolithic and Middle Stone Age. Boston (MA): Springer, pp. 29-56. https://doi. org/10.1007/0-387-24661-4_3 
Claude, J. 2008. Morphometrics with $R$ New York: Springer.

Crampton, J.S. 1995. Elliptic Fourier Shape Analysis of Fossil Bivalves: Some Practical Considerations. Lethaia, 28: 179-86. https://doi.org/10.1111/j.1502-3931.1995. tb01611.x

Damlien, H., Berg-Hansen, I.M., Zagorska, I., Kalniņš, M., Nielsen, S.V., Koxvold, L.U., et al. 2018. A Technological Crossroads: Exploring Diversity in the Pressure Blade Technology of Mesolithic Latvia. Oxford Journal of Archaeology, 37: 229-46. https://doi.org/10.1111/ojoa.12139

Dev, S. \& Riede, F. 2012. Quantitative Functional Analysis of Late Glacial Projectile Points from Northern Europe. Lithics, 33: 40-55.

Ekholm, G. 1926. Lyngby-Kultur. In: M. Ebert, ed. Reallexikon der Vorgeschichte. Band 7. Berlin: Walter de Gruyter, pp. 324-26.

Felgenhauer, F. 1996. Aggsbachien - Gravettien - Pavlovien. Zur Frage nomenklatorischer Prioritäten in der Urgeschichtsforschung. Mitteilungen der Anthropologischen Gesellschaft in Wien, 125-6: 249-57.

Fellner, R. 1995. Technology or Typology? A Response to Neeley \& Barton. Antiquity, 69: 381-83. https://doi.org/10.1017/ S0003598X00064796

Fischer, A. 1985. Late Paleolithic Finds. In: K. Kristiansen, ed. Archaeological Formation Processes: The Representativity of Archaeological Remains from Danish Prehistory. Copenhagen: Nationalmuseet, pp. 81-88.

Fischer, A. 1991. Pioneers in Deglaciated Landscapes: The Expansion and Adaptation of Late Palaeolithic Societies in Southern Scandinavia. In: R.N.E. Barton, A.J. Roberts \& D.A. Roe, eds. Late Glacial in North-West Europe: Human Adaptation and Environmental Change at the End of the Pleistocene (CBA Research Report 77). London: Council for British Archaeology, pp. 100-22.

Gamble, C., Davies, W., Pettitt, P., Hazelwood, L. \& Richards, M. 2005. The Archaeological and Genetic Foundations of the European Population during the Late Glacial: Implications for 'Agricultural Thinking'. Cambridge Archaeological Journal 15: 193-223. https://doi.org/10. 1017/S0959774305000107
Gero, J. \& Mazzullo, J. 1984. Analysis of Artifact Shape Using Fourier Series in Closed Form. Journal of Field Archaeology, 11: 315-22.

Goring-Morris, A.N. 1996. Square Pegs into Round Holes: A Critique of Neeley \& Barton. Antiquity, 70: 130-35. https://doi. org/10.1017/S0003598X00082958

Houtsma, P., Kramer, E., Newell, R.R. \& Smit, J.L. 1996. The Late Palaeolitbic Habitation of Haule V: From Excavation Report to the Reconstruction of Federmesser Settlement Patterns and Land-use. Assen: Van Gorcum.

Iovita, R. 2009. Ontogenetic Scaling and Lithic Systematics: Method and Application. Journal of Archaeological Science, 36: 1447-57. https://doi.org/10.1016/j.jas.2009.02.008

Iovita, R. 2010. Comparing Stone Tool Resharpening Trajectories with the Aid of Elliptical Fourier Analysis. In: S. Lycett \& P. Chauhan, eds. New Perspectives on Old Stones: Analytical Approaches to Paleolitbic Technologies. New York: Springer, pp. 235-53.

Iovita, R., Tuvi-Arad, I., Moncel, M.-H., Despriée, J., Voinchet, P. \& Bahain, J.-J. 2017. High Handaxe Symmetry at the Beginning of the European Acheulian: The Data from la Noira (France) in Context. PLoS ONE, 12: e0177063. https:// doi.org/10.1371/journal.pone.0177063

Ivanovaite, L. \& Riede, F. 2018. The Final Palaeolithic Hunter-Gatherer Colonisation of Lithuania in Light of Recent Palaeoenvironmental Research. Open Quaternary, 4: 4. https://doi.org/10.5334/ oq.39

Johansen, L. 2000. The Late Palaeolithic in Denmark. In: B. Valentin, P. Bodu \& M. Christiensen, eds. L'Europe centrale et septentrionale au Tardiglaciaire (Mémoire du Musée de Préhistoire d'Ile-de-France 7). Nemours: Association pour la Promotion de la Recherche Archéologique en Ile de France, pp. 197-215.

Kaufman, D. 1995. Microburins and Microliths of the Levantine Epipalaeolithic: A Comment on the Paper by Neely \& Barton. Antiquity, 69: 375-81. https://doi. org/10.1017/S0003598X00064784

Klecka, W. 1980. Discriminant Analysis (Quantitative Applications in Social Sciences 19). Beverley Hills: SAGE. 
Kobusiewicz, M. 2002. Ahrensburgian and Sviderian: Two Different Modes of Adaptation? In: B.V. Eriksen \& B. Bratlund, eds. Recent Studies in the Final Palaeolithic of the European Plain: Proceedings of a UISPP Symposium, Stockholm, 1-1 October 1999. Højbjerg: Jutland Archaeological Society, pp. 117-22.

Kobusiewicz, M. 2009a. The Lyngby Point as a Cultural Marker. In: M.J. Street, R.N.E. Barton \& T. Terberger, eds. Humans, Environment and Chronology of the Late Glacial of the North European Plain. Mainz: Römisch-Germanischs Zentralmuseums, pp. 169-78.

Kobusiewicz, M. 2009b. Whether the Bromme Culture Existed? Folia Praehistorica Posnaniensia, 15: 75-91.

Kolasau, A.U. 2018. Grensk Culture in Eastern Belarus: The Current State of Research. Archaeologia Baltica, 25: 22-34.

Kovarovic, K., Aielo, L.C., Cardini, A. \& Lockwood, C.A. 2011. Discriminant Function Analyses in Archaeology: Are Classification Rates too Good to be True? Journal of Archaeological Science, 38: 3006-18. https://doi.org/10.1016/j.jas.2011. 06.028

Kozłowski, J.K. \& Kozłowski, S.K. 1979. Upper Palaeolithic and Mesolithic in Europe: Taxonomy and Palaeohistory. Wrocław: Zakład Narodowy imienia Ossolińskich.

Kozłowski, S.K. 1991. Le Desnenien. Antbropologie, 29: 95-100.

Kozłowski, S.K. 1999. The Tanged Points Complex. In: S.K. Kozłowski, J. Gurba \& L.L. Zaliznyak, eds. Tanged Point Cultures in Europe: International Archaeological Symposium, Lublin, September, 13-16, 1993. Lublin: Maria Curie-Sklodowska University Press, pp. 28-146.

Lisitsyn, S.N. 2017. An Ecological Approach to the Periodization of the Final Palaeolithic and Early Mesolithic in the Upper Volga Basin. Stratum Plus, 1: 59-110.

Lopes, D.M. 2009. Drawing in a Social Science: Lithic Illustration. Perspectives on Science, 17: 5-25.

Madsen, B. 1992. Hamburgkulturens flintteknologi i Jels (The Hamburgian Flint Technology at Jels). In: J. Holm \& F. Rieck, eds. Istidsjegere ved Jelssøerne (Skrifter fra Museumsrådet for Sønderjyllands Amt 5). Haderslev: Haderslev Museum, pp. 93-131.
Marwick, B. 2017. Computational Reproducibility in Archaeological Research: Basic Principles and a Case Study of their Implementation. Journal of Archaeological Method and Theory, 24: 424-50. https://doi. org/10.1007/s10816-015-9272-9

Mathiassen, T. 1946. En senglacial boplads ved Bromme. Aarboger for nordisk Oldkyndighed og Historie, 1946: 121-97.

McGarigal, K., Stafford, S. \& Cushman, S. 2000. Multivariate Statistics for Wildlife and Ecology Research. New York: Springer.

Neeley, M.P. \& Barton, C.M. 1994. A New Approach to Interpreting Late Pleistocene Microlith Industries in Southwest Asia. Antiquity, 68: 275-88. https://doi.org/10. 1017/S0003598X00046585

O’Brien, M.J. \& Lyman, R. 1999. Seriation, Stratigraphy, and Index Fossils: The Backbone of Archaeological Dating. New York: Kluwer Academic/Plenum.

O'Brien, M.J., Buchanan, B. \& Eren, M.I. 2018. Convergent Evolution in StoneTool Technology. Cambridge (MA): MIT Press.

O'Brien, M.J., Lyman, R.L., Collard, M., Holden, C.J., Gray, R.D. \& Shennan, S.J. 2008. Transmission, Phylogenetics, and the Evolution of Cultural Diversity. In: M.J. O'Brien, ed. Cultural Transmission and Archaeology: Issues and Case Studies. Washington, DC: Society for American Archaeology Press, pp. 39-58.

Otte, M. \& Keeley, L.H. 1990. The Impact of Regionalism on Palaeolithic Studies. Current Anthropology, 31: 577-82.

Phillips, J.L. 1996. The Real Nature of Variability of Levantine Epipalaeolithic Assemblages. Antiquity, 70: 137-38. https:// doi.org/10.1017/S0003598X00082971

R Development Core Team. 2017. R: A Language and Environment for Statistical Computing. R Foundation for Statistical Computing, Vienna, Austria. URL https://www.R-project.org/

Rasmussen, L.W. \& Richter, J. eds. 1991. Kainsbakke: En kystboplads fra yngre stenalder. Grenå: Djurslands Museum/Dansk Fiskerimuseum.

Reimer, P.J., Bard, E., Bayliss, A., Beck, J.W., Blackwell, P.G., Bronk Ramsey, C., et al. 2013. IntCal13 and Marine13 Radiocarbon Age Calibration Curves 0-50,000 Years cal BP. Radiocarbon, 55: 1869-87. https://doi. org/10.2458/azu_js_rc.55.16947 
Riede, F. 2009. The Loss and Re-introduction of Bow-and-Arrow Technology: A Case Study from the Northern European Late Paleolithic. Lithic Technology, 34: 27-45. https://doi.org/10.1080/01977261.2009. 11721072

Riede, F. 2014. The Resettlement of Northern Europe. In: V. Cummings, P. Jordan \& M. Zvelebil, eds. The Oxford Handbook of the Archaeology and Anthropology of HunterGatherers. Oxford: Oxford University Press, pp. 556-81.

Riede, F. 2017. The 'Bromme problem': Notes on Understanding the Federmessergruppen and Bromme Culture Occupation in Southern Scandinavia during the Allerød and early Younger Dryas Chronozones. In: M. Sørensen \& K. Buck Pedersen, eds. Problems in Palaeolithic and Mesolitbic Research. Copenhagen: University of Copenhagen \& Museum of Southeast Denmark, pp. 61-85.

Riede, F., Hoggard, C. \& Shennan, S. 2019. Reconciling Material Cultures in Archaeology with Genetic Data Requires Robust Cultural Evolutionary Taxonomies. Palgrave Communications, 5, 55. https://doi. org/10.1057/s41599-019-0260-7

Rimantienè, R. 1971. Paleolit i mezolit Litvy. Vilnius: Mintis.

Rimantienė, R. 1999. Margiu 1-oji gyvenvietè. Lietuvos archaeologija, 16: 109-70.

Roberts, B.W. \& Vander Linden, M. eds. 2011. Investigating Archaeological Cultures: Material Culture, Variability, and Transmission. New York: Springer.

Rohlf, F.J. 2015. The tps Series of Software. Hystrix, the Italian Journal of Mammalogy, 26: 9-12. https://doi.org/10.4404/hystrix26.1-11264

Rohlf, F.J. \& Archie, J.W. 1984. A Comparison of Fourier Methods for the Description of Wing Shape in Mosquitoes (Diptera: Culicidae). Systematic Zoology, 33: 302-17. https://doi.org/10.2307/ 2413076

Salomonsson, B. 1964. Découverte d'une habitation du Tardi-glaciaire à Segebro, Scanie, Suède. Acta Archaeologica, 35: $1-28$.

Saragusti, I., Karasik, A., Sharon, I. \& Smilansky, U. 2005. Quantitative Analysis of Shape Attributes Based on Contours and Section Profiles in Artifact Analysis.
Journal of Archaeological Science, 32: 841-53. https://doi.org/10.1016/j.jas.2005.01.002

Šatavičius, E. 2016. The First Palaeolithic Inhabitants and the Mesolithic in Lithuanian Territory. In: G. Zabiela, Z. Baubonis \& E. Marcinkeviciute, eds. $A$ Hundred Years of Archaeological Discoveries in Lithuania. Vilnius: Society of Lithuanian Archaeology, pp. 8-39.

Sauer, F. \& Riede, F. 2019. A Critical Reassessment of Cultural Taxonomies in the Central European Late Palaeolithic. Journal of Archaeological Method and Theory, 26: 155-84. https://doi.org/10. 1007/s10816-018-9368-0

Schild, R. 1996. The North European Plain and Eastern Sub-Balticum between 12,700 and 8000 BP. In: L.G. Straus, B.V. Eriksen \& D.R. Yesner, eds. Humans at the End of the Ice Age. London: Plenum, pp. 129-57.

Serwatka, K. 2015. Bifaces in Plain Sight: Testing Elliptical Fourier Analysis in Identifying Reduction Effects on Late Middle Palaeolithic Bifacial Tools. Litikum: A Kókor Kerekasztal Folyóirata/Journal of Litbic Research Roundtable, 3: 13-25.

Serwatka, K. 2018. What's your Point? Flexible Projectile Weapon System in the Central European Final Palaeolithic: The Case of Swiderian Points. Journal of Archaeological Science Reports, 17: 263-78. https://doi.org/ 10.1016/j.jasrep.2017.10.048

Serwatka, K. \& Riede, F. 2016. 2D Geometric Morphometric Analysis Casts Doubt on the Validity of Large Tanged Points as Cultural Markers in the European Final Palaeolithic. Journal of Archaeological Science Reports, 9: 150-59. https://doi.org/ 10.1016/j.jasrep.2016.07.018

Shea, J.J. 2014. Sink the Mousterian? Named Stone Tool Industries (NASTIES) as Obstacles to Investigating Hominin Evolutionary Relationships in the Later Middle Paleolithic Levant. Quaternary International, 350: 169-79. https://doi.org/ 10.1016/j.quaint.2014.01.024

Shennan, S. 1997. Quantifying Archaeology. Edinburgh: Edinburgh University Press.

Shott, M.J. 1997. Stones and Shafts Redux: The Metric Discrimination of ChippedStone Dart and Arrow Points. American Antiquity, 62: 86-101. https://doi.org/10. 2307/282380 
Siemaszko, J. 1999a. Stone Age Settlement in the Lega Valley Microregion of NorthEast Poland. European Journal of Archaeology, 2: 293-312. https://doi.org/ 10.1179/eja.1999.2.3.293

Siemaszko, J. 1999b. Tanged Points in the Basins of Lega and Elk Rivers. In: J.K. Kozłowski, J. Gurba \& L.L. Zaliznyak, eds. Tanged Point Cultures in Europe: International Archaeological Symposium. Lublin, September, 13-16, 1993. Lublin: Maria Curie-Sklodowska University Press, pp. 186-93.

Simpson, G.G. 1945. The Principles of Classification and a Classification of Mammals. (Bulletin of the American Museum of Natural History, 85). New York: American Museum of Natural History.

Sinitsyna, G. 2002. Lyngby Points in Eastern Europe. Archaeologia Baltica, 5: 83-93.

Sinitsyna, G. 2004. The Late Palaeolithic of the Valdai Region. In: P. Crombé \& P. Vermeersch, eds. Le Mésolithique: Actes du XIVème Congrès UISPP, Université de Liège, Belgique, 2-8 septembre 2001 / The Mesolithi. Acts of the 14th UISPP Congress, University of Liège, Belgium, 2-8 September 2001 (BAR International Series 1302). Oxford: Archaeopress, pp. 227-34.

Sinitsyna, G. 2013. O migratsiiach i avtochtonnom razvitii kultur finalnogo paleolita na severo-zapade Russkoi ravniny. In: G. Sinitsyna, ed. Problemy zaseleniia severozapada Vostochnoi Evropy v verkhnem $i$ finalnom paleolite (kulturno-istoricheskikbie protsesy). St Petersburg: Rossiiskaya akademya nayk, pp. 152-81.

Sinopoli, C.M. 1991. Style in Arrows: A Study of an Ethnographic Collection From the Western United States. In: P.T. Miracle, L.E. Fisher \& J. Brown, eds. Foragers in Context: Long-term, Regional and Historical Perspectives in HunterGatherer Studies. Ann Arbor (MI): University of Michigan Press, pp. 63-87.

Sorokin, A.N. 2009. Finalnyi paleolit i mezolit Centralnoy Rossii. In: A. Sorokin, S.V. Oshibkina \& A.V. Trusov, eds. Na perelome epokh. Moskva: Rossiiskaya akademya nayk, pp. 127-251.

Sulgostowska, Z. 1989. O podstawach wydzielania kultury perstuńskiej (na marginesie dwóch prac Karola Szymczaka). Archeologia Polski, 34: 429-36.
Szymczak, K. 1983. Pótnocno-wschodnia prowincja surowcowa kultury świderskiej. Warszaw: Warsaw University.

Szymczak, K. 1987. Perstunian Culture: The Eastern Equivalent of the Lyngby Culture in the Neman Basin. In: J.M. Burdukiewicz \& M. Kobusiewicz, eds. Late Glacial in Central Europe: Culture and Environment. Wrocław: Ossolineum, pp. 267-76.

Szymczak, K. 1990. Odpowiedź na artykuł Zofii Sulgostowskiej 'O podstawach wydzielenia kultury perstuńskiej'. Archeologia Polski, 35: 105-20.

Szymczak, K. 1991. Odpowiedź na artykuł Zofii Sulgostowskiej 'O podstawach wydzielania kultury perestuńskiej. Archeologia Polski, 35: 341-46.

Szymczak, K. 1992. Pótnocno-wschodnia prowincja surowcowa kultury świderskiej (Acta Universitatis Lodziensis, Folia Archaeologica, 15). Łódź: University of Łódź.

Szymczak, K. 1995. Epoka kamienia Polski pót nocno-wschodniej na tle środkowoeuropejskim. Warsaw: ENTER.

Szymczak, K. 1999. Late Palaeolithic Cultural Units with Tanged Points in North Eastern Poland. In: S.K. Kozłowski \& L. L. Zaliznyak, eds. Tanged Point Cultures in Europe: International Archaeological Symposium. Lublin, September, 13-16, 1993. Lublin: Maria Curie-Sklodowska University Press, pp. 93-101.

Taute, W. 1968. Die Stielspitzen-Gruppen im nördlichen Mitteleuropa. Ein Beitrag zur Kenntnis der späten Altsteinzeit. Köln: Böhlau.

Tomášková, S. 2003. Nationalism, Local Histories and the Making of Data in Archaeology. Journal of the Royal Anthropological Institute, 9: 485-507. https://doi.org/10.1111/1467-9655.00160

Tostevin, G.B. 2013. Seeing Lithics: A Middlerange Theory for Testing for Cultural Transmission in the Pleistocene (American School of Prehistoric Research Monograph). Oxford \& Oakville (CT): Oxbow Books.

Vasil'ev, S.A. 2001. The Final Paleolithic in Northern Asia: Lithic Assemblage Diversity and Explanatory Models. Arctic Anthropology, 38: 3-30.

Villalba-Mouco, V., van de Loosdrecht, M.S., Posth, C., Mora, R., Martinez- 
Moreno, J., Rojo-Guerra, M., et al. 2019. Survival of the Late Pleistocene Hunter-Gatherer Ancestry in the Iberian Peninsula. Current Biology, 29: 1169-77. https://doi.org/10.1016/j.cub. 2019.02.006

Wiessner, P. 1983. Style and Social Information in Kalahari San Projectile Points. American Antiquity, 48: 253-76. https://doi.org/10.2307/280450

Wygal, B.T. \& Heidenreich, S.M. 2014. Deglaciation and Human Colonization of Northern Europe. Journal of World Prehistory, 27: 111-44. https://doi.org/10. 1007/s10963-014-9075-z

Wyszomirska-Webert, B. 1996. All These Fantastic Cultures? Concepts of Archaeological Cultures, Identity and Ethnicity. Archaeologia Polona, 34: 97-128.

Yu, G., Smith, D.K., Zhu, H., Guan, Y. \& Tsan-Yuk Lam, T. 2017. Ggtree: An R Package for Visualization and Annotation of Phylogenetic Trees with their Covariates and Other Associated Data. Methods in Ecology and Evolution, 8: 28-36. https:// doi.org/10.1111/2041-210X.12628

Zaliznyak, L.L. 1999. Finalnyi paleolit pivnichnogo zachodu Shidnoi Evropy. Kiev: Dodatok do Naukovich zapisok NaUKMA.

\section{Biographical Notes}

Livija Ivanovaite is an archaeologist at the Museum of Copenhagen. Her main research interests are the Final Palaeolithic of Europe and the initial colonization of higher latitudes after the Last Glacial Maximum.

Address: Livija Ivanovaite, Museum of Copenhagen, Stormgade 20, 1555 Copenhagen, Denmark. [email: 1934@ $\mathrm{kk} . \mathrm{dk}]$.

ORCID: 0000-0001-8499-3772.

Kamil Serwatka is is the head of the Department of Palaeolithic and Mesolithic in the Archaeological and Ethnographic Museum in Eódź (Central Poland). Currently, his research focuses on hunter- gatherer projectile technologies in the past and present, lithic technology, and artefact classification.

Address: Kamil Serwatka, Palaeolithic and Mesolithic Department, Archaeological and Ethnographic Museum in Eódź, Wolności 14, 91-415, Łódź, Poland. [email: kamserw@gmail.com].

Christian Steven Hoggard is a Visiting Fellow at the Department of Archaeology and Anthropology at the University of Southampton in the UK. His research focuses on quantitative approaches to the European Palaeolithic and the suitability of geometric morphometric methodologies for stone tool analysis.

Address: Christian Steven Hoggard, Department of Archaeology and Anthropology, University of Southampton, Highfield Road, Southampton SO17 1BF, UK. [email: C.S.Hoggard@soton.ac.uk]. ORCID: 0000-0002-0022-3605.

Florian Sauer is scientist and sub-project director within the German Research Council-funded consortium CRC 806 'Our Way to Europe'. His work is focused on the Palaeolithic and Mesolithic of Europe and the Near East and draws heavily on biogeographic methods as implemented in GIS approaches.

Address: Florian Sauer, Archaeological Institute, University of Cologne, Kerpener Straße 30, 50931, Köln, Germany. [email: florian.sauer@uni-koeln.de]._ ORCID: 0000-0001-9687-4762.

Felix Riede is Professor of Climate Change Archaeology and Environmental Humanities at Aarhus University in 
Denmark. His research focuses on the Palaeolithic and Mesolithic of Europe, cultural transmission and human vulnerability and resilience to natural disasters and climate change.
Address: Felix Riede, Department of Archaeology and Heritage Studies, Aarhus University, Moesgård Allé 20, 8270 Højbjerg, Denmark. [email: f.riede@cas. au.dk]. ORCID: 0000-0002-4879-7157.

\title{
Toutes ces cultures fantastiques? Historiographie et régionalisation des cultures à pointes à pédoncule de la fin du Paléolithique en Europe de l'Est
}

\begin{abstract}
Le Tardiglaciaire, c'est-à-dire l'époque allant du premier réchauffement notable après le dernier maximum glaciaire jusqu'au début de l'Holocène (environ 16000 à 11700 cal BP), a traditionnellement été considéré comme une phase de recolonisation de l'Europe du Nord et une période de diversification des cultures de la fin du Paléolithique. Ces cultures ont été définies par des types d'outils spécifiques ou par leur apparition simultanée ou encore par leur fréquence relative. En Europe du Nord-Est, l'existence de nombreuses cultures a ainsi été proposée sur la base de pointes à pédoncule apparemment différentes. Cette pratique de nommer de nouveaux groupes culturels sur la base de différences présumées a fait l'objet de critiques répétées mais sans que des alternatives convaincantes aient été formulées. Dans cet article les auteurs passent en revue le paysage taxonomique des cultures à grandes pointes à pédoncule de la fin de Paléolithique en Europe de l'Est tel qu'il se présente de nos jours, ce qui les mène à exprimer des doutes sur la validité épistémologique de bien de ces groupements culturels. Par conséquent, les auteurs se sont attelés à l'examen d'une classe d'objet fondamentale, les grandes pointes à pédoncule, en utilisant les méthodes de la morphométrie géométrique. Ils peuvent ainsi démontrer qu'il est difficile d'identifier des groupes distincts, ce qui a des conséquences majeures pour notre comprébension des tendances et processus de changement culturel à cette époque en Europe du Nord-Est et peut-être ailleurs. Translation by Madeleine Hummler
\end{abstract}

Mots-clés: fin du Paléolithique, historiographie, morphométrie géométrique, Europe de l'Est, taxonomies culturelles, grandes pointes à pédoncule

\section{Alle diese fantastischen Kulturen? Forschungsgeschichte und Regionalisierung der großen Stielspitzenkulturen im späten Paläolithikum Osteuropas}

Das Spätglazial, also der Zeitraum zwischen der ersten ausgeprägten Klimaerwärmung nach dem letzten eiszeitlichen Maximum bis zum Anfang des Holozäns (ca. 16 000-11 700 cal BP), ist traditionell als eine Epoche der Wiederbesiedlung Nordeuropas und der Diversifizierung der spätpaläolithischen Kulturen angesehen worden. Diese Kulturen sind von spezifischen Artefakttypen, oder derer gleichzeitigen Erscheinung, oder noch aufgrund derer relativen Häufigkeit, charakterisiert. In Nordosteuropa sind zahlreiche Kulturen auf der Grundlage von vermeintlich verschiedene Stielspitzen vorgeschlagen worden. Diese Namengebung von neuen Kulturgruppen aufgrund wahrgenommener Unterschiede ist wiederholt kritisiert worden, aber solide Alternativen sind bisher selten vorgeschlagen worden. Hier wird die taxonomische Gestaltung der großen spätpaläolithischen Stielspitzen in Osteuropa, wie sie zurzeit konzipiert ist, bewertet; die epistemologische Gültigkeit von zahlreichen Gruppen muss man deswegen mit Vorsicht beurteilen. Diese Situation hat uns dazu motiviert, eine fundamentale Artefaktkategorie, nämlich die großen Stielspitzen, mithilfe von geometrischen morphometrischen Methoden zu untersuchen. Dies zeigt, dass es schwierig ist, zwischen verschiedenen Gruppen zu unterscheiden; dies hat wesentliche Auswirkungen auf unser Verständnis von kulturellen Wandlungsprozessen und Tendenzen in diesem Zeitabschnitt in Nordosteuropa und vielleicht auch anderswo. Translation by Madeleine Hummler

Stichworte: spätes Paläolithikum, Forschungsgeschichte, geometrische morphometrische Methoden, Osteuropa, kulturelle Taxonomie, große Stielspitzen 